\title{
DETERMINANT FACTORS OF THE STOCK RETURN IN MANUFACTURING COMPANIES LISTED IN THE INDONESIAN STOCK EXCHANGE IN THE PERIOD OF 2013 - 2015
}

\author{
Rendy Lee \\ Program Studi Magister Manajemen Universitas Tarumanagara \\ rendylee1@yahoo.com
}

\begin{abstract}
This study aims to investigate the effects of Earnings per Share, Price Earnings Ratio, and Debt to Equity Ratio, both partially and simultaneously, on the Stock Return of manufacturing companies listed in the Indonesian Stock Exchange. The period of the study was 2013 - 2015. This was an associative study aiming to investigate the effects or relationships of two or more variables. The research sample, consisting of 35 companies, was selected by means of the purposive sampling technique with the research period of 2013 2015. The data analysis technique to answer the research problems was the panel data regression analysis technique using the program of EViews. The results of the study showed that EPS had a significant positive effect on the stock return; this was indicated by the value of $t$ statistics of 2,928136 and a significance value of 0.0074. PER did not have a significant positive effect on the stock return; this was indicated by the value of $t$ statistics of 0,095663 and a significance level of 0,9241 . DER had a significant negative effect on the stock return; this was indicated by the value of $t$ statistics of -0.307209 and a significance value of 0,7596 .
\end{abstract}

Keyword: Earnings per Share, Price Earnings Ratio, Debt to Equity Ratio, Price to Book Value

\section{Pendahuluan}

Perekonomian pada masa sekarang ini mengalami perkembangan pesat. Orang mulai melakukan transaksi ekonomi melalui berbagai cara, salah satunya yaitu dengan menginvestasikan harta atau uangnya melalui pasar modal. Pasar modal mempertemukan antara pihak yang memiliki kelebihan dana dengan pihak yang membutuhkan dana dengan cara memperjual belikan sekuritas (Tandelilin, 2007). Dengan adanya pasar modal maka para investor dapat menginvestasikan dananya tersebut ke dalam perusahaan.

Tujuan utama investor melakukan investasi adalah untuk memperoleh keuntungan (return) yang tinggi. Bagi para investor, return merupakan salah satu parameter untuk menilai seberapa besar keuntungan suatu saham. Investor yang akan berinvestasi di pasar modal terlebih dahulu melihat saham perusahaan mana yang paling menguntungkan, dengan menilai kinerja perusahaan yang bersangkutan. Perusahaan yang memiliki kinerja cukup baik akan lebih diminati oleh para investor, karena kinerja perusahaan mempengaruhi harga saham di pasar. Investor akan membeli saham sesuai kinerja perusahaan saat ini dan prospeknya di masa yang akan datang. Oleh karena itu, kinerja perusahaan yang meningkat akan berpengaruh pada meningkatnya harga saham dan diharapkan return saham yang dapat diterima investor meningkat.

Melihat fakta bahwa tidak ada kepastian mengenai return yang akan didapatkan oleh investor ketika melakukan investasi saham, tentu seorang investor tidak ingin melakukan kesalahan dalam pengambilan keputusan investasi. Oleh karena itu, perlu diketahui faktorfaktor yang mempengaruhi return saham, sehingga harapan untuk memperoleh return yang maksimal dapat tercapai. 


\section{Tujuan Penelitian}

Tujuan dari penelitian ini adalah untuk melihat bagaimana pengaruh earning per share, price earning ratio dan debt equity ratio memiliki pengaruh terhadap return saham.

\section{Earning Per Share}

Menurut Sutrisno (2007:223), Earnings Per Share atau laba per lembar saham merupakan ukuran kemampuan perusahaan untuk menghasilkan keuntungan per lembar saham pemilik. Laba yang digunakan sebagai ukuran adalah laba bagi pemilik atau EAT. Semakin besar nilai Earnings per Share tentu akan menguntungkan bagi pemegang saham karena semakin besar juga keuntungan yang disediakan oleh perusahaan untuk pemegang saham. Bagi para investor maupun calon investor, informasi ini merupakan salah satu faktor fundamental yang sangat mempengaruhi dalam pengambilan keputusan.

\section{Price Earning Ratio}

Price Earnings Ratio (PER) membandingkan antara harga saham (yang diperoleh dari pasar modal) dan laba per lembar saham yang diperoleh pemilik perusahaan (disajikan dalam laporan keuangan) (Husnan, 2005:75). Sedangkan menurut Mahmud dan Halim (2003:85) PER merupakan bagian dari rasio pasar, dimana sudut pandang rasio pasar ini lebih banyak berdasarkan pada sudut investor atau calon investor. Keinginan investor melakukan analisis kesehatan suatu saham melalui rasio - rasio keuangan seperti PER, dikarenakan adanya keinginan investor atau calon investor akan hasil (return) yang layak atas suatu investasi saham.

\section{Debt to Equity Ratio}

Debt to equity ratio adalah rasio yang memberikan gambaran mengenai struktur modal yang dimiliki perusahaan atau keseimbangan proporsi antara aktiva yang didanai oleh kreditor dan yang didanai oleh pemilik perusahaan, sehingga dapat dilihat tingkat resiko tak tertagihnya suatu utang (Prastowo dan Juliaty, 2002:84). Menurut Brigham dan Houston (2006: 103) perusahaan dengan debt to equity yang rendah akan memiliki risiko kerugian yang kecil ketika keadaan ekonomi mengalami kemerosotan, namun ketika kondisi ekonomi membaik, kesempatan dalam memperoleh laba juga rendah. Sebaliknya perusahaan dengan rasio leverage yang tinggi memang menanggung risiko kerugian yang besar pula ketika perekonomian sedang merosot, tetapi dalam keadaan baik, perusahaan ini memiliki kesempatan memperoleh laba besar. Perusahaan dengan laba yang tinggi akan mampu membayar dividen yang lebih tinggi, sehingga berkaitan dengan laba perlembar saham yang akan naik karena tingkat utang yang lebih tinggi, maka leverage akan dapat menaikkan harga saham (Brigham dan Houston, 2006: 24).

\section{Hipotesis Penelitian}

Hubungan antar variabel independen dengan variable dependen digambarkan dalam kerangka hipotesis berikut ini.

Variabel Independen

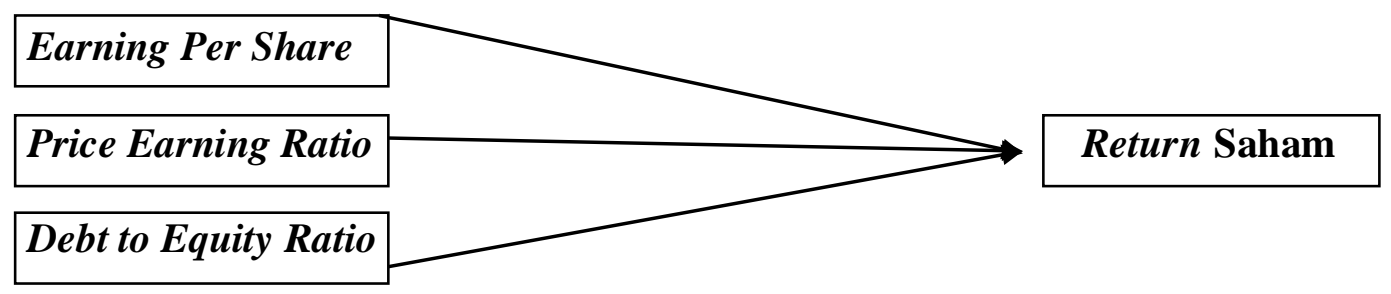


Dari landasan konseptual dan tinjauan pustaka yang telah diuraikan, dapat disusun beberapa hipotesis penelitian sebagai berikut:

H1 : Terdapat pengaruh positif dan signifikan Earnings per Share terhadap return saham pada perusahaan manufaktur yang terdaftar di BEI periode 2013-2015.

H2 : Terdapat pengaruh positif dan signifikan Price Earnings Ratio terhadap return saham pada perusahaan manufaktur yang terdaftar di BEI periode 2013-2015.

H3 : Terdapat pengaruh negatif dan signifikan Debt to Equity Ratio terhadap return saham pada perusahaan manufaktur yang terdaftar di BEI periode 2013-2015.

\section{Metode Penelitian}

Teknik sampel yang digunakan dalam penelitian ini adalah purposive sampling method, yaitu metode pengambilan sampel dengan tujuan penelitian.Dengan metode ini, sampel sengaja dipilih untuk dapat mewakili populasinya.Kriteria yang digunakan untuk memilih sampel adalah (1) Perusahaan manufaktur yang terdaftar di BEI dari 2013 sampai 2015. (2) Perusahaan yang mempunyai data laporan keuangan yang terdaftar di BEI dari tahun 2013 sampai 2015. (3) Perusahaan yang mempunyai data laporan keuangan per 31 desember yang sudah diaudit untuk tahun 2013 sampai 2015. (4) Bursa efek tidak melakukan delisting pada perusahaan yang bersangkutan selama periode penelitian. (5) Perusahaan manufaktur memiliki earning per share (EPS) bernilai positif selama $2013-2015$.

1. Operasionalisasi Variabel

Variabel yang dipakai dalam penelitian ini diambil dari laporan keuangan pada periode 2013 - 2015 untuk variabel independen.Dalam penelitian ini variabel penelitian dikelompokkan menjadi dua variabel yaitu variabel tergantung (dependen variabel) dan variabel bebas (independen variabel).Variabel tergantung adalah return saham ( $\mathrm{Y}$ ) dan variael bebas adalah $(\mathrm{X})$ yang terdiri earning per share $(\mathrm{X} 1)$, price earning ratio $(\mathrm{X} 2)$, dan debt to equity ratio $(\mathrm{X} 3)$.

a. Variabel Independen

b.

\section{Earnings Per Share (EPS)}

Rasio earning per share digunakan untuk mengukur kemampuan perusahaan dalam menghasilkan keuntungan setiap lembar saham.Earnings per share menunjukkan besarnya laba atau keuntungan yang diperoleh pemegang saham setiap lembar sahamnya. EPS dapat dihitung dengan rumus:

$$
\text { Earning Per Share }=\frac{\text { laba bersih setelah bunga dan pajak }}{\text { jumlah saham yang beredar }}
$$

\section{Price Earning Ratio (PER)}

Price Earnings Ratio digunakan untuk mengukur pertumbuhan laba perusahaan. Rasio ini menunjukkan besarnya harga yang harus dibayar oleh investor untuk mendapatkan satu rupiah earnings perusahaan.Price Earnings Ratio menghubungkan antara harga setiap lembar sahamnya dengan laba per lembar saham. Secara sistematis PER dirumuskan sebagai berikut:

$$
\text { Price Earning Ratio }=\frac{\text { Harga Saham }}{\text { Laba per lembar saham }}
$$

\section{Debt to Equity Ratio (DER)}


Debt to Equity Ratio menghubungkan antara total utang dengan modal sendiri. Debt to Equity Ratio digunakan untuk mengukur tingkat leverage dalam memenuhi utang jangka panjang. Rasio ini menggambarkan struktur modal perusahaan yang didanai oleh kreditur dan didanai oleh pemilik perusahaan. Rasio ini dapat dihitung dengan rumus sebagai berikut:

$$
\text { Debt to Equity Ratio }=\frac{\text { Total Kewajiban }}{\text { Modal Sendiri }}
$$

c. Variabel Dependen

Return saham merupakan tingkat pengembalian atau tingkat keuntungan yang diterima oleh investor dari hasil investasi yang dilakukannya. Setiap orang yang melakukan investasi pasti mengharapkan keuntungan. Tanpa adanya keuntungan dari hasil investasi, investor tidak akan berinvestasi. Return saham bisa dihitung menggunakan rumus sebagai berikut:

$$
\text { Rit }=\text { Pit }- \text { Pit }_{-1} /_{\text {Pit }}-1 X_{100 \%}
$$

\section{Keterangan:}

Rit = tingkat keuntungan saham I pada periode $\mathrm{t}$

Pit = harga penutupan saham I pada periode $t$ (harga penutupan)

Pit-1= harga penutupan saham I pada periode sebelumnya (harga penutupan)

\section{Persamaan Statistik}

Dalam penelitian ini metode analisis data yang digunakan adalah analisis regresi linier berganda (multiple linier regression method) dengan pengolahan data menggunakan software Eviews (Views Ekonometrik) versi 8. Dengan demikian persamaan statistik dapat dinyatakan sebagai berikut :

$\mathrm{R}=\beta \mathrm{o}+\beta 1 \mathrm{EPS}+\beta 2 \mathrm{PER}+\beta 3 \mathrm{DER}+$ ei

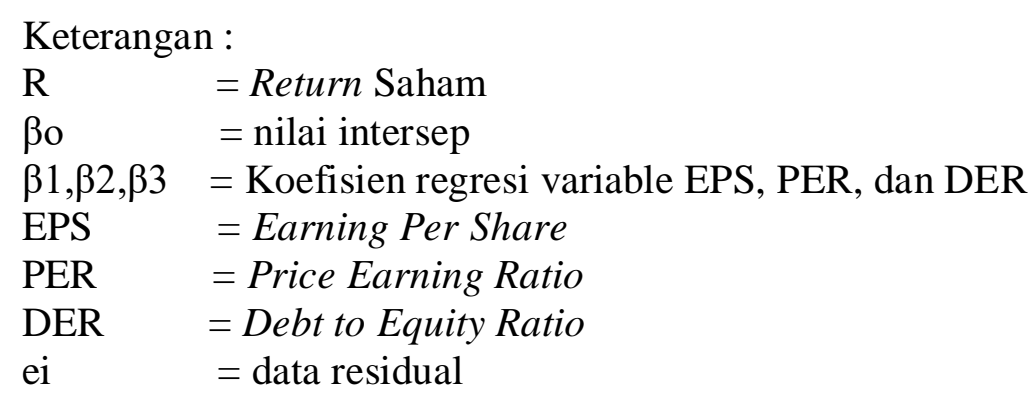

\section{Hasil dan Pembahasan}

a) Pengaruh EPS terhadap Return Saham pada perusahaan manufaktur yang terdaftar di BEI periode 2013 - 2015.

Variabel EPS memiliki koefisien regresi bernilai positif sebesar 0,406681 dan nilai signifikansi sebesar 0,0074. Nilai signifikansi tersebut kurang dari toleransi kesalahan yaitu $5 \%$, maka dapat disimpulkan bahwa variabel EPS berpengaruh positif dan signifikan terhadap return saham. EPS menunjukkan besarnya laba atau keuntungan yang diperoleh pemegang saham setiap lembar sahamnya. Apabila Earnings Per Share (EPS) perusahaan tinggi, maka akan banyak investor yang mau membeli saham dari perusahaan tersebut. Semakin banyak 
permintaan saham akan berdampak pada naiknya harga saham. Semakin tinggi harga saham berarti kemungkinan untuk memperoleh return yang tinggi pun dapat dicapai.

b) Pengaruh PER terhadap Return Saham pada perusahaan manufaktur yang terdaftar di BEI periode 2013 - 2015.

Variabel PER memiliki koefisien regresi sebesar 0.0000926 dan nilai signifikansi sebesar 0,9241. Nilai signifikansi tersebut lebih dari toleransi kesalahan yaitu 5\%, maka dapat disimpulkan bahwa variable PER tidak berpengaruh negatif dan tidak signifikan terhadap Return Saham. PER dapat memberikan petunjuk mengenai apa yang dipikirkan investor atas kinerja perusahaan dimasa lalu dan prospeknya dimasa yang akan datang. Dari hasil penelitian ini, koefisien regresi PER bernilai positive, hal ini berarti semakin tinggi PER maka semakin tinggi return saham dan sebaliknya semakin rendah PER semakin rendah return saham.

c) Pengaruh DER terhadap Return Saham pada perusahaan manufaktur yang terdaftar di BEI periode $2013-2015$

Variabel DER memiliki koefisien regresi negatif sebesar -0,168701 dan nilai signifikansi DER sebesar 0,7596. Nilai signifikansi tersebut kurang dari toleransi kesalahan yaitu 5\%, maka dapat disimpulkan bahwa variable DER berpengaruh negatif dan tidak signifikan terhadap return saham.

\section{Kesimpulan}

Berdasarkan hasil analisis dan pembahasan yang telah dijelaskan di bab sebelumnya, dapat disimpulkan sebagai berikut:

1) Terdapat Pengaruh positif dan signifikan Earnings Per Share (EPS) terhadap Return Saham pada perusahaan manufaktur yang terd aftar di BEI periode 2013 - 2015. Hal ini ditunjukkan dengan nilai koefisien sebesar 0,406681 dan nilai signifikansi 0,0074 yang berada di bawah 0,05 (tingkat signifikansi=5\%), sehingga dapat disimpulkan bahwa hipotesis 1 terbukti.

2) Tidak terdapat pengaruh negatif dan signifikan Price Earnings Ratio (PER) terhadap Return Saham pada perusahaan manufaktur yang terdaftar di BEI periode 2013 2015. Hal ini ditunjukkan dengan nilai koefisien sebesar 0,000926 dan nilai signifikansi 0,9241 yang berada di atas 0,05 (tingkat signifikansi=5\%), sehingga dapat disimpulkan bahwa hipotesis 2 tidak terbukti. Penelitian ini justru menemukan PER berpengaruh negatif dan tidak signifikan terhadap Return Saham.

3) Terdapat pengaruh negative dan tidak signifikan Debt to Equity Ratio (DER) terhadap Return Saham pada perusahaan manufaktur yang terdaftar di BEI periode 2013 2015. Hal ini ditunjukkan dengan nilai koefisien sebesar $-0,168701$ dan nilai signifikansi 0,7596 yang berada di atas 0,05 (tingkat signifikansi $=5 \%$ ), sehingga dapat disimpulkan bahwa hipotesis 3 tidak terbukti.

4) Koefisien determinasi (R2) pada penelitian ini diperoleh sebesar 0,5297 Atau 52,97\%, ini menunjukkan kemampuan variable independen dalam Menjelaskan variasi variable dependen adalah sebesar 52,97\%. 


\section{Daftar Pustaka}

Afwan, Muhamad Muzid. (2013). Pengaruh PER, Dividend Yield dan Market to Book Value Ratio terhadap Return Saham pada Perusahaan yang Terdaftar di Bursa Efek Indonesia Periode 2009 - 2010. Skripsi Fakultas Ekonomi Universitas Negeri Yogyakarta.

Arista, Desy. (2012). Analisis Faktor - Faktor yang Mempengaruhi Return Saham (Kasus pada Perusahaan Manufaktur yang Go Public Di BEI Periode Tahun 2005 - 2009). Jurnal Ilmu Manajemen dan Akutansi Terapan Vol 3 Nomor 1, Mei 2012.

Baridwan, Zaki. (2010). Intermediate Accounting, Edisi 8. Yogyakarta: BPFE.

Brigham, E F. dan Houston, J F. (2006). Dasar-dasar Manajemen Keuangan Cetakan Sepuluh. Jakarta: Salemba Empat.

Farkhan dan Ika. (2012). Pengaruh Rasio Keuangan terhadap Return Saham Perusahaan Manufaktur di Bursa Efek Indonesia. Jurnal Bisnis dan Manajemen.Vol 9, No 1.

Ghozali, Imam. (2006). Aplikasi Analisis Multivariate dengan Program SPSS. Cetalam IV, Semarang: Badan Penerbit Univesitas Dipenogoro.

Hadi, Nor. (2013). Pasar Modal (Acuan Teoritis dan Praktis Investasi di Instrumen Keuangan Pasar Modal). Yogyakarta: Graha Ilmu.

Hartati. (2010). Pengaruh Return On Asset (ROA), Debt To Equity Ratio (DER), EarningPershare (EPS), Price Earning Ratio (PER) terhadap Return Saham. Skripsi Fakultas Ekonomi Universitas Sebelas Maret.

Hartono, Jogiyanto (2010). Teori Portofolio dan Analisis Investasi. Yogyakarta: BPFE

Husnan Suad dan Pudjiastuti Eny. (2002). Dasar - dasar Manajemen Keuangan. Yogyakarta: AMP YKPN.

Ikatan Akuntan Indonesia. (2012). Standar Akuntansi Keuangan. Jakarta: Penerbit Salemba Empat.

Iskandar, Alwi Z. (2003). Pasar Modal Teori dan Aplikasi, Edisi Pertama. Jakarta: Penerbit Yayasan Pancur Siwah.

Ismanto, Hadi. (2011). Analisis Pengaruh Ukuran Perusahan, Book - to - Market Value, dan Beta terhadap Return Saham Di BEI. Jurnal Ekonomi dan Pendidikan. Vol 8, No 2, November 2012.

Mohamad Samsul. (2006). Pasar Modal dan Manajemen Portofolio. Surabaya: Erlangga.

Tandelilin, Eduardus. (2001). Analisis Investasi dan Manajemen Portofolio. Yogyakarta: BPFE

Tandelilin, Eduardus. (2007). Analisis Investasi dan Manajemen Portofolio. Yogyakarta: BPFE Undang-Undang RI No. 8 Tahun 1995. Tentang Pasar Modal.

Usman Yulianty. (2004). Analisis Pengaruh EVA, MVA, dan Kinerja Keuangan Konvensional terhadap Return Saham di Bursa Efek Jakarta. Tesis Magister Manajemen Universitas Diponegoro. 
Van Horne, J C and Walker, J M. (2005). Prinsip-Prinsip Manajemen Keuangan.Buku 2. Jakarta: Salemba Empat.

Reeve, James M., Carl S. Warren, Jonathan E. Duchac. (2009). Principles of Accounting. $23^{r d}$ Edition. USA: Thomson co.

Robert Ang. (1997). Buku Pintar Pasar Modal Indonesia . Jakarta: Media Staff Indonesia. www.idx.co.id 
